\title{
7. Electing women to Parliament: Fiji and the alternative vote electoral system
} \begin{abstract}
In many places in the world, women struggle to be heard and, when it comes to having a voice in the highest authority in the land, the difficulties in some countries can be almost insurmountable. Women in Fiji are confronting the problem of women's representation in Parliament. With only a small number of women (7.04 percent) in the House of Representatives, what changes could the citizens of Fiji make to remedy this lack of female representation? One answer that could be considered is for Fijian lawmakers to make amendments to the alternative vote electoral system, a variation on preferential voting. The alternative vote falls into the same simple plurality category as first-past-the-post, a system notoriously unfriendly to women candidates.
\end{abstract}

RAE NICHOLL

University of the South Pacific

It is vitally important that all structures of Government, including the President, should understand fully that freedom cannot be achieved unless women have been emancipated from all forms of oppression (Nelson Mandela, 1994). ${ }^{1}$

$\mathrm{I}$ N MANY places in the world, women struggle to be heard and, when it comes to having a voice in the highest authority in the land, the difficulties in some countries can be almost insurmountable. Women in Fiji are confronting the problem of women's representation in Parliament. With only a small number of women (7.04 percent) in the House of Representatives, 


\section{CONTEMPORARY GENDER ISSUES}

what changes could the citizens of Fiji undertake to remedy this lack of female representation? One answer that could be considered is for Fijian lawmakers to make amendments to the alternative vote electoral system, a variation on preferential voting. The alternative vote falls into the same simple plurality category as first-past-the-post, a system notoriously unfriendly to women candidates.

\section{The position of women in Fijian society}

Recent statistics show that Fiji has total population including men, women and children of 825,478, of which women make up exactly 49 percent $^{2}$ and that the female literacy rate is 91 percent ( 95 percent for men) ${ }^{3}$ yet women's role in decision-making at the highest level is minimal. One reason for this lack of female visibility is the focus on racial divisions in Fiji, which has resulted in the neglect of the gender gap. Political parties and political scientists have been so uninterested in women in politics in Fiji that it is only now, at the beginning of the 21 st century, that research is beginning to recover the names and histories of the few women who have served in Parliament. ${ }^{4}$

Until recently, the same accusation could be made of political leaders, who have not shown any obvious interest in encouraging the participation of women in the running of the nation. For instance, in his autobiography, The Pacific Way: A Memoir, the former Prime Minister and President, Ratu Sir Kamisese Mara, noted in just one line that women had been given the vote but made no mention of their contribution to the productivity of the country. ${ }^{5}$ It is only very recently that Fijian women have enjoyed a highly visible and vocal advocate of their cause: Vice-President Ratu Joni Maidraiwiwi. Ratu Joni has advocated strongly on behalf of women and is a firm believer in the ability of women to take their place in Parliament and in the running of the nation. Addressing a group of representatives from Fijian women's organisations in 2004, he said:

Quite simply, you have a right to be heard. Enveloped in that right, is the right to lead and participate in decisions. They affect you and yet your voices are not sufficiently heard because there are not enough of you to reflect your opinions. Tradition and religion too often abet politics in seeking to restrict you to a certain space and place. Engage them in a gentle but a firm manner and only confront as a last resort. There 
will be times when there is little choice, but then profound and meaningful change often requires conflict. Do not be afraid. Your cause is just and your sisters who are unwilling or unable to participate, owing to various constraints, repose their hopes and dreams in you. ${ }^{6}$

When the Government ratified the Convention on the Elimination of all Forms of Discrimination against Women (CEDAW) in 1995, the women of Fiji gained the protection of international law. As well, the Bill of Rights, contained within the 1997 Constitution of the Fiji Islands, promises that 'every person has the right to equality before the law' and that 'a person must not be unfairly discriminated against, directly or indirectly, on the ground of his or her actual or supposed personal characteristics or circumstances, including ... gender'. ${ }^{7}$ Despite this guarantee, the Constitution has not been able to assist women to gain an equal partnership in governing the country. For that purpose, we must examine the alternative vote and gauge whether this electoral system is unfairly discriminating against women.

This article does not discuss the question of gender quotas or other forms of affirmative action; neither does it consider other obstacles to the advancement of women into the legislature such as the problem of incumbency.

\section{The parliamentary system}

Fiji has a bicameral parliamentary system consisting of a House of Representatives and a Senate. The 1997 Constitution allowed for the House of Representatives to consist of 71 members representing single-member constituencies. ${ }^{8}$ Of the 71 members, voters who are registered on one of four separate communal rolls, depending on whether they are Fijians, Indians, Rotumans or 'others', elect 46 members. People from Rotuma are ethnically, linguistically and culturally distinct from other people in the Pacific. Although their island is part of Fiji, they are accorded special status in the Constitution and have one reserved seat in Parliament. Voters registered as 'others' are citizens of Fiji who belong to ethnic groups other than Fijian, Indian or Rotuman: they could be European, Chinese or people originally from other Pacific Islands. Finally, voters elect the remaining 25 members to the House of Representatives from all communities registered on an open electoral roll. ${ }^{9}$ As of November 2005, six women sit in the House of Representatives; although only four won on the night of the election in August 2001, two have won byelections subsequently. ${ }^{10}$ 


\section{CONTEMPORARY GENDER ISSUES}

The Senate consists of 32 members appointed by the President of Fiji on the advice of the major political players within Fiji: the Bose Levu Vakaturaga (Great Council of Chiefs), the Prime Minister, the Leader of the Opposition, and the Council of Rotuma. The Senate carries out a review role, scrutinising and revising Bills sent to it by the House of Representatives. It can pass a Bill with or without amendment, reject it, or agree to it in an amended form but, ultimately, it has no veto powers.

While the emphasis in this article is primarily on elected members, following the 2001 election, four women were appointed to sit in the Senate. The number of women in the Senate has been higher in the past. In 1999, eight women were appointed during the brief period that the Fiji Labour Party was the Government. That Government was overthrown in a coup d'etat in 2000. Subsequently, an election was held in 2001, which was won by the Soqosoqo Duavata Ni Lewenivanua (SDL) party. At that time, the number of women appointed to the Senate reverted to four (Table 1) although the government subsequently added one more woman senator in November 2005, taking the total to five. ${ }^{11}$

\section{Women, the vote, and representation}

Ian McAllister and Donley Studlar have identified three independent variables that provide a good explanation for the success, or otherwise, of women's quest to enter Parliament. These variables are: the date at which women received the vote, which indicates the political culture in the country concerned; the introduction of gender quotas within political parties; and the type of electoral system. ${ }^{12}$

By taking New Zealand, South Africa and Fiji as examples of countries that achieved female enfranchisement at very different times, it is clear that McAllister and Studlar's assertion that the date of female enfranchisement is an important variable contributing to the number of women in legislatures does not hold in every case. New Zealand became the first country in the world to give women the right to vote in general elections on 19 September 1893, after suffragists had organised a long and strategic campaign. In 1919 women won the right to stand as candidates and the first woman was elected to the New Zealand Parliament in 1933. After that time, women's representation increased slowly until 1984, when progress accelerated. Following the 2005 elections, women constituted 32.2 percent of members in the House of Representatives, the highest percentage ever. ${ }^{13}$

90 PACIFIC JOURNALISM REVIEW 12 (1) 2006 
CONTEMPORARY GENDER ISSUES

\begin{tabular}{|llll|}
\hline \multicolumn{3}{|c|}{ Table 1: Fft: Women appointed to the Senate-1994-2001 } \\
\hline Election date & Total of Senators & $\begin{array}{l}\text { No. of women } \\
\text { appointed }\end{array}$ & $\begin{array}{l}\text { \% Women in } \\
\text { Senate }\end{array}$ \\
021994 & 34 & 3 & 8.8 \\
051999 & 32 & 8 & 25.0 \\
082001 & 32 & 4 & 12.5 \\
\hline
\end{tabular}

A contrasting example of a country where citizens won the right to vote and stand for Parliament only recently is South Africa. It was not until 1994, when the apartheid era came to an end after a long struggle for freedom, that the vast majority of people were finally enfranchised. Following the 1994 elections, the South African Parliament became - for the first time everrepresentative of people from all races and both genders. From the start, women were well represented, achieving 26.3 percent in the 1994 election. The 2004 election resulted in women winning 32.8 percent of the seats in the National Assembly, South Africa's lower house. ${ }^{14}$ After 10 years of democracy, South Africa now has a slightly higher percentage of women in its legislature than does New Zealand, where women have had the vote for 112 years.

Clearly, the date at which women in Fiji received the vote has had no bearing on their representation in Parliament. Unlike women in New Zealand and South Africa, women in Fiji did not fight for the vote or for the right to stand in elections. Rather, all Fiji citizens were given both these rights in 1963. ${ }^{15}$ Nearly 40 years had passed at the time of the 2001 elections, yet only four women (5.6 percent) were elected to the House of Representatives, ${ }^{16}$ although, as the result of by-elections, this number had risen to six $(8.45$ percent) by November 2005 .

The second variable mentioned by McAllister and Studlar - the use of gender quotas by political parties - has not been attempted in Fiji as yet and consequently cannot be discussed here. The third variable, the voting system, needs to be examined closely as the evidence suggests that the alternative vote system will inevitably fail to assist women enter the political arena.

\section{Majoritarian systems}

Cross-national investigations have shown consistently that the electoral system is the most important variable when it comes to assessing the level of representation of women in legislatures. ${ }^{17}$ Two main electoral systems exist, 


\section{CONTEMPORARY GENDER ISSUES}

plurality systems and proportional representation systems, although variations exist within both methods.

Prior to the change to the alternative vote in 1999, Fiji used the simple plurality or majoritarian system known as first-past-the-post in countries that adopted the Westminster system of government or winner-takes-all in the United States. The appeal of first-past-the-post lies in its simplicity. A country is divided into single-member constituencies also known as electorates or districts. Each elector has one vote and the candidate who receives the most votes in each constituency at a general election is elected a Member of Parliament. ${ }^{18}$ First-past-the-post produces two major parties that often alternate in power, resulting in strong and stable governments. Both the United States and the United Kingdom continue to use first-past-the-post. Drawbacks occur in the system when more than two parties are competing to become the Government. For instance, in a situation where there are multiple candidates standing in an electorate, a candidate receiving far less than a majority of the votes may be elected. Former Fijian Prime Minister Sitiveni Rabuka commented that:

\footnotetext{
One of the observations we made in looking at [the Review of the Constitution of 1990] was that amongst ourselves in Parliament there were members who were elected into Parliament by less than 20 percent of the voters in their constituency. And we asked ourselves whether they really could stand up and say that they were speaking on behalf of the people in their constituency. ${ }^{19}$
}

This problem may be compounded nationwide, resulting in a party becoming Government because it has won the majority of seats but it may have received fewer votes nationally than the opposition party. For the reasons mentioned, first-past-the-post also makes it extremely difficult for small parties to gain seats, resulting in a Parliament that does not represent the diversity of people living in the state.

Another major problem with first-past-the-post is that it is not fair to women as it can have a negative effect on the selection of female candidates. A well-documented phenomenon of electoral systems with single member districts or constituencies is the 'tyranny of small decisions' ${ }^{20}$ Andrew Reeve and Alan Ware found that the task of selecting a candidate for a particular 
constituency usually fell on party elites within an electorate who were 'obliged to make choices covering a range or a time span too small to take all relevant factors into account'. It was their sole responsibility to decide on one candidate - they had no influence over candidate selections in other districts. Faced with choosing one candidate, the selectors tended to pick the one who they believed would be the best overall candidate for their particular seat. This tended to be a middle-class male. The result was that the 'tyranny of small decisions' was incremental and resulted in a non-representative legislature. ${ }^{19}$ Political scientist Wilma Rule concurred with this finding - she noted that it is too risky for political elites to back a woman candidate in districts where only one person is elected. ${ }^{22}$

\section{Alternative vote system}

In 1997, a new Constitution was introduced in the Fiji Islands, bringing about considerable change, including the reconfiguration of the electoral rolls and the provision of reserved seats in Parliament for Fijians, Indians, Rotumans and 'others', the group of people who make up the residue of Fiji citizenry. First-past-the-post was replaced by a preferential voting system called the alternative vote, which is used in the Australian House of Representatives. ${ }^{23}$

The alternative vote is a majoritarian system very similar to first-pastthe-post in that it is based on single-member electorates. Unlike first-pastthe-post, the alternative vote gives electors the choice of ranking candidates in order of preference. Alternatively, they may accept preferences already chosen by their preferred politician or political party. If voters decide to accept their party's preferences, they tick their ballot paper 'above the line'. If they do not agree with the pre-selected preferences, then they must vote 'below the line', being very careful to accurately number their preferences as votes will be declared invalid if they make a mistake in the numbering. Voters in Fiji receive two voting papers - one vote for their communal seat constituency and one vote for their open seat constituency, which are usually filled out in identical fashion, that is, either 'above' or 'below the line'. ${ }^{24}$

Clearly, the alternative vote does very little to give a voice to those who have been traditionally under-represented in Parliament, ${ }^{25}$ such as women. As Andrew Reynolds noted, the 'tyranny of small decisions' continues under the alternative vote system: 


\section{CONTEMPORARY GENDER ISSUES}

Plurality-majority single-member district systems, whether of the AngloAmerican first-past-the-post variety, the Australian preference ballot alternative vote, or the French two-round system, are deemed to be particularly unfavourable to women's chances of being elected to office. Each of these systems creates an incentive for party bosses to stand lowest-common denominator candidates in geographical districts; these rarely turn out to be women or minorities. ${ }^{26}$

It is possible that women in Fiji were persuaded that the new system would bring more women into Parliament. When the alternative vote was first introduced, there was a considerable increase in female candidates, from 12 in 1994 to 27 in 1999, but this momentum was not maintained, there being only a slight increase to 31 in 2001 (Table 2).

\begin{tabular}{|llll|}
\hline Table 2: & Fffl: Women candidates & $-1992-2001^{27}$ & \\
\hline Election & $\begin{array}{l}\text { No. of women } \\
\text { candidates }\end{array}$ & $\begin{array}{l}\text { No. elected } \\
\text { to House of Reps }\end{array}$ & $\begin{array}{l}\text { Total no. of } \\
\text { elected seats }\end{array}$ \\
1994 & 12 & 3 & 70 \\
1999 & 27 & 8 & 71 \\
2001 & 31 & 5 & 71 \\
\hline
\end{tabular}

Source: Dharma Chandra, D. and Lewai, V. (2005). Women and men of Fiji Islands: Gender statistics and trends. Suva: Population Studies Programme, University of the South Pacific, p. 124.

In addition to the increase in candidates in 1999, the first election under the alternative vote system more than doubled the number of women in the legislature from three to eight. Unfortunately, this increase proved to be short lived and, following the 2001 election, the position of women in the House of Representatives halved from eight to four, a number similar to that achieved under first-past-the-post (Table 3).

The 2006 general election will take place during the week May 6-13, again using the alternative vote electoral system. Although some political parties, including the ruling SDL, stated publicly that the number of women candidates would increase at this election, as yet there is no evidence that this eventuated.

Besides being unfair to women, the alternative vote has other major flaws. According to the United Kingdom's Electoral Reform Society, 'research by Democratic Audit in 1997 showed that the results [from the alternative vote] 
CONTEMPORARY GENDER ISSUES

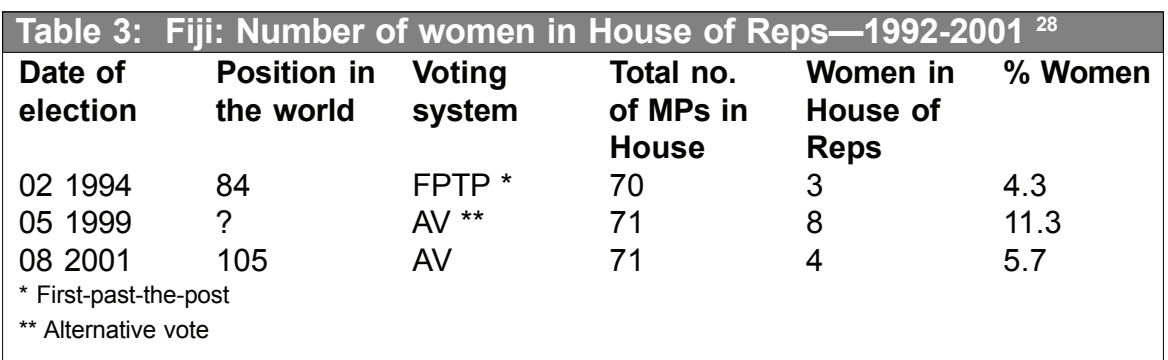

could actually be even more distorting than under first-past-the-post' ${ }^{29}$ This distortion was explained by Fiji Islands academic Wadan Narsey:

If you have 71 constituencies and in each of these 71 constituencies one party, A, manages to get 51 percent of the votes either by first-pastthe-post or by the alternative vote method, that party A will win all 71 seats. And the party which has got 49 percent of the votes in the entire country will have no seats whatsoever in Parliament. ${ }^{30}$

\section{Proportional representation}

Proportional representation is an electoral system that ensures the number of seats a party gains is more or less equivalent to the number of votes it receives nationwide. Two major types of proportional representation are in use around the world. These are party list systems (used in South Africa) and the single transferable vote (STV). There are also mixed systems using both single-member constituencies and party lists: New Zealand's Mixed-Member Proportional system (MMP) falls into this category.

Rule has noted that the differences between party-list proportional representation and single-member district systems are the most important factors affecting women's share of legislative seats. ${ }^{31}$ The reasons for these differences are not fully understood although a number of theories have been suggested. One answer could be that the structural features of the electoral system may help women. ${ }^{32}$ For instance, in proportional representation systems, parties tend to balance their tickets by including viable female candidates on the party list in order to appeal to a broad segment of the electorate. ${ }^{33}$ Vernon Bogdanor suggested:

For whereas under a single-member constituency system it is the presence of a candidate who deviates from the identikit norm (whether fe- 


\section{CONTEMPORARY GENDER ISSUES}

male or minority) that is noticed, in a party list system it is the absence of a woman or a minority candidate, the failure to present a balanced ticket, that will be commented upon and resented. ${ }^{35}$

Obviously, this method of ticket balancing is impossible in single-member constituencies where only one person carries the party banner. ${ }^{33}$

\section{Speeding up the process}

Besides achieving higher proportions of women legislators, research by Matland and Studlar shows another interesting phenomenon when countries change to proportional representation systems. The increase in the proportion of women MPs has been, and continues to be, much faster under proportional systems than under single-member district systems (see Table 4). ${ }^{36}$

\section{Table 4: Percent of women MPs across 23 legislatures-1945-1993}

\begin{tabular}{|c|c|c|c|c|c|c|c|}
\hline System & 1945 & 1950 & 1960 & 1970 & 1980 & 1990 & 1993 \\
\hline $\begin{array}{l}\text { Single-member district } \\
\text { systems * }\end{array}$ & 3.1 & 2.1 & 2.5 & 2.2 & 3.4 & 8.2 & 9.5 \\
\hline $\begin{array}{l}\text { Proportional } \\
\text { representation ** }\end{array}$ & 3.2 & 5.1 & 5.9 & 6.0 & 11.8 & 18.4 & 20.2 \\
\hline
\end{tabular}

Source: Matland, R. E. and Studlar, D. T. (1996). The contagion of women candidates in single-member district and proportional representation electoral systems: Canada and Norway. In The Journal of Politics, Vol. 58, No. 3 , August, p. 710

While a moderate gap existed between the two electoral systems from post-World War II until 1970, after that date there has been a substantial and significant increase in the gender gap. In 1945, the difference between the two systems was only 0.1 percent, but this gap widened to 3.8 percent in 1970 and to 8.4 percent in 1980. By 1993, the difference between the two systems had reached 10.7 percent. In just over 20 years, female representation jumped in the countries with proportional representation from 6.0 percent in 1970 to 20.2 percent in 1993, an increase of 14.1 percent. During the same period, the proportion of women MPs in countries with first-past-the-post moved from 
just 2.2 percent in 1970 to only 9.47 percent by 1993, an increase of 7.24 percent, or almost half the increase enjoyed by women under proportional systems.

\section{The party list system}

Under proportional representation systems, a good percentage of women may be chosen to appear on the list but problems frequently arise at the stage when the list is ordered or ranked. The Nordic women were the first to understand the significance of the list-ranking or rank-ordering system. Theorists such as Ingunn Norderval, Torild Skard and Elina Haavio-Mannila were concerned about proportional representation systems because they realised that 'the basic impact of proportional representation systems upon female representation is complicated by the presence of rank-ordering arrangements' ${ }^{37}$ Fewer women candidates were selected when the chance for electoral success was high, a finding that holds true for all electoral systems. In general, party elites try to balance their list by choosing candidates to represent all major geographical areas, trade unions (in the case of socialist parties), youth, women and various occupational groupings. In the ensuing juggling act, many good candidates may be dropped from consideration because they do not meet the various balancing criteria. ${ }^{38}$

Countries using list systems opt for either open or closed lists. Each party's list is presented to the voters as either 'closed' or 'open'. Under the open list system, electors can vote for individuals and are able to change the position of candidates on lists. Finland uses a variation of this system. Closed systems mean that voters are restricted to voting for the whole list of candidates who have already been ranked in order and whose names may, or may not, appear on the ballot paper. Voters in closed systems are not able to change the order in which the candidates have been ranked. ${ }^{39}$ New Zealand and South Africa use closed lists, as do Norway and Sweden. ${ }^{40}$

When we consider Fiji, South Africa and New Zealand, it is clear that the two countries which changed from first-past-the-post to proportional representation have achieved considerable success for their women while Fiji, which replaced one majoritarian system with another, has not made similar headway (Table 5). 
CONTEMPORARY GENDER ISSUES

\begin{tabular}{|c|c|c|c|c|c|}
\hline & $\begin{array}{l}\text { Date } \\
\text { women } \\
\text { received } \\
\text { the vote }\end{array}$ & $\begin{array}{l}\text { Date } \\
\text { women } \\
\text { could stand } \\
\text { for } \\
\text { Parliament }\end{array}$ & $\begin{array}{l}\text { Date of } \\
\text { the last } \\
\text { election }\end{array}$ & $\begin{array}{l}\% \text { of women } \\
\text { elected in } \\
\text { last election } \\
\text { - Lower } \\
\text { House }\end{array}$ & $\begin{array}{l}\text { Voting } \\
\text { system } \\
\text { used }\end{array}$ \\
\hline $\begin{array}{l}\text { New } \\
\text { Zealand }\end{array}$ & 1893 & 1919 & 2005 & $32.2 \%$ & $\begin{array}{l}\text { Proport. } \\
\text { represent. } \\
\text { - mixed } \\
\text { member }\end{array}$ \\
\hline Fiji & 1963 & 1963 & 2001 & $7.04 \%$ & Alternative \\
\hline $\begin{array}{l}\text { South } \\
\text { Africa }\end{array}$ & 1994 & 1994 & 2004 & $32.8 \%$ & $\begin{array}{l}\text { Proport. } \\
\text { represent. } \\
\text { - closed }\end{array}$ \\
\hline
\end{tabular}

Source: Inter-Parliamentary Union, Women in National Parliaments.

www,.ipu.org/wmn-e/arc/classif040202.htm (21 November 2005).

\section{Single transferable vote (STV)}

STV is another form of proportional representation. The system is based on multi-member electorates, which vary in size. This system allows voters to rank their preferences within each electorate resulting in a parliament that is proportionate to the wishes of the voters. Research conflicts about whether STV is good for female representation and also whether or not the size of each multi-member electorate - the district magnitude - is significant. For instance, Malta has used STV since 1920 and has 13 multi-member constituencies, each constituency having a uniform number of five available seats. Even so, Malta has always had a poor record for electing women. On the other hand, district magnitudes in Ireland vary from three to five seats. ${ }^{42}$ When researching the election of women to the Irish Dail, Richard Engstrom discovered that more women are nominated and elected to districts with a magnitude of four or five rather than to those electing only three members. $\mathrm{He}$ suggested that those interested in improving the electoral opportunities for women, both in Ireland and elsewhere, should give serious consideration to increasing the size of district magnitudes. ${ }^{43}$

\section{District magnitude and proportional representation}

When studying 23 parliamentary democracies using proportional representation, Rule found that list systems, in particular those with large district 
magnitudes, were an important factor in explaining women's representation. ${ }^{44}$ Even countries with small district magnitudes, ranging from three to six members, were more successful in electing women legislators than states with single-member districts. The Nordic countries, which are the most successful at electing women, had a wide range of district magnitudes. For instance, Finland had an average of 13 candidates per district; Sweden an average of 12; Denmark an average of 10; and Norway had district magnitude ranges from two to 16 seats, giving an average of seven. ${ }^{45}$ Finally, the list component of New Zealand's MMP system is 60 and is nationwide.

\section{District magnitude and first-past-the-post}

In elections in the states of the United States where first-past-the-post is the voting system, the research into whether women are more likely to run and be elected in multi-member districts rather than in single-member districts is inconclusive. ${ }^{46}$ A comprehensive study by R. Darcy, Susan Welch and Janet Clark in 1989 into 14 American state legislatures that used first-past-the-post found conclusive evidence that more women run and get elected in multimember districts than in single-member districts. ${ }^{47}$ In 1990, Welch and Studlar reported evidence to the contrary. Their research showed that multi-member districts 'make up a small and inconsistent difference to the electability of women in state elections in the United States' and that the minor differences that were detected may have been caused by other factors such as the effects of urbanisation. ${ }^{48}$ Adding to these conflicting views, a United Nations report in 1992 claimed that research showed 'a positive relationship between district size and the number of women elected. The larger the district, the more women elected.' ${ }^{49}$

\section{Guam, women and districting}

If women in Fiji are looking for a model where a Pacific island has achieved a high female presence in the legislature, they should look at Guam. Guam is an unincorporated territory of the United States and operates under the same two-party (Democrats and Republicans) simple plurality or first-past-the-post voting system that is used in many American states. Members are elected every two years to the 15-seat Guam Legislature from multi-member lists: electors are given as many votes as there are seats to fill. ${ }^{50}$ Between the years 1982 and 1996, election results for women in Guam were consistently higher 
CONTEMPORARY GENDER ISSUES

\begin{tabular}{|llll|}
\hline Table 6: Guam: General election results-1988-2004 & \\
\hline $\begin{array}{l}\text { Year of } \\
\text { Election }\end{array}$ & $\begin{array}{l}\text { Total no. of } \\
\text { seats }\end{array}$ & Women & $\begin{array}{l}\text { \% of } \\
\text { women }\end{array}$ \\
1988 & 21 & 7 & 33.3 \\
1990 & 21 & 6 & 28.8 \\
1992 & 21 & 6 & 28.8 \\
1994 & 21 & 6 & 23.8 \\
1996 & 21 & 5 & 23.8 \\
1998 & 15 & 2 & 13.3 \\
(No. of seats & & & \\
reduced to 15) & 15 & 3 & 20.0 \\
2000 & 15 & 5 & 33.3 \\
2002 & 15 & 3 & 20.0 \\
2004 & & & \\
\hline
\end{tabular}

Source: Guam Election Commission, www.guamelection.org and Kuam Com, Pacific Telestations, Guam. www.kuam.com/decision2002/generalelection/results.asp

than might be expected under first-past-the-post, reaching 28.6 percent in 1996. After that date, the numbers of women started to drop when the size of the legislature was reduced from 21 to 15 members in 1998. The number of women recovered in 2002, when five women were elected (33.3 percent)

As no research had been undertaken on the effect of district magnitude on the electoral success of women in Guam, I have applied the model used in the United States by Darcy, Welch and Clark to the Guam situation. The authors looked at whether 'multi-member-district plurality systems encouraged the election of women in the United States in the same way that multi-member list proportional representation systems appear to have done in continental Europe'. ${ }^{51}$

Darcy, Welch and Clark's research confirmed that women did benefit from multi-member districts and the authors suggested that women's success was based on four main findings. First, they found that, because women were seen as a significant and legitimate political group, parties were under pressure to include them as candidates. ${ }^{52}$ Second, they thought that in districts where women were under-represented, voters applied their own form of affirmative action in favour of female candidates. Third, a woman running on a predominantly male team of candidates may attract attention because of her novelty value. This, in turn, could lead to greater name recognition by voters and enhance her chances of winning election. Finally, women may be more

100 PACIFIC JOURNALISM REVIEW 12 (1) 2006 
willing to put themselves forward for election in multi-member districts rather than single-member districts. This could be because many women prefer to campaign on their own behalf, supported by their qualifications, achievements and programmes, and dislike an adversarial contest where they must oppose a particular candidate. Women may feel more comfortable in a multimember-district election in which there is no specific opponent, the authors argued. ${ }^{53}$

During my research in Guam in 1995, women politicians confirmed all the points made by Darcy, Welch and Clark, except for the last suggestion, that women prefer to stand on a multi-member platform because of their dislike of confrontation. Interviewees mentioned the pressure that political parties found themselves under to attract credible female candidates; and they stressed their need for name recognition. When asked whether they preferred at-large or multi-member districts, the women politicians overwhelmingly endorsed at-large elections. ${ }^{54}$

The question of the optimum district magnitude for women in first-pastthe-post systems remains unresolved. Darcy, Welch and Clark noted that the size of the multi-member district appeared to bear no relation to the proportion of women elected, although they did suggest that political parties were under greater pressure to run viable women candidates in districts of more than three members compared to single-member districts. ${ }^{55}$ (The researchers did not reveal the specific district magnitudes involved in their research.) Another study by Welch and Studlar involved district magnitudes ranging from one to 12 but, as with the previous research, they found no evidence that any particular district magnitude was a threshold or 'the best' for women's electability. ${ }^{56}$

\section{Summary}

In summary, two points have been discussed relating to the efficacy - or otherwise - of different electoral systems in enhancing women's legislative representation. First, the number of women elected to legislatures under firstpast-the-post systems has lagged far behind the number of women elected under proportional systems. Second, there has been a much slower increase in women legislators in countries with first-past-the-post even though similar social pressures have been applied across all democracies since the mid-1960s to increase women's legislative representation. ${ }^{57}$ The evidence is conclusive 


\section{CONTEMPORARY GENDER ISSUES}

that women perform better under proportional representation, especially list systems, and that single-member constituency systems are the worst for women.

Where majoritarian and first-past-the-post voting systems are used, there is one slight hope for improving women's electoral success. The example here is Guam where, instead of the more usual single-member electorates, the island has a multi-member district comprising the 15 seats that make up the Guam Legislature. Even where first-past-the-post prevails, an electorate that has multi-members can achieve considerable electoral success for women.

When the Fiji Islands changed its voting system from first-past-the-post to the preferential system known as the alternative vote, the nation did women no favours. One form of single-district system has been exchanged for another single-district system. Women in Fiji cannot look to the alternative vote to help them achieve their political ambitions. On the other hand, if lawmakers are serious about placing more women in decision-making, they could consider changing the voting system and replacing single-member districts with multiple-member districts. In that way, the 'tyranny of small decisions' might be avoided and political parties compelled to construct party lists that reflect more fairly both genders in the Fiji Islands.

\section{Notes}

1 Mandela, N. (1994). Speech by President Nelson Mandela opening South Africa's first democratically elected parliament on 24 May 1994. Braamfontein, Commission on Gender Equality.

2 The 2002 statistics show that there are 404,821 women out of a total of 825,478 men in Fiji. (See Fiji Department of Statistics, www.statsfiji.gov.fj/Key\%20Stats/Population/2.4estimated\%20population.pdf ).

3 United Nations Children's Fund (2005). www.unicef.org/infobycountry/ fiji_statistics.html.

4 Rasigatale, M. (2003). Ro Teimumu—A Fijian princess, Fiji, Mak Heritage. This is the only full length contemporary autobiography or biography I have found devoted to a Fijian woman.

5 Mara, Ratu Sir Kamisese (1997). The Pacific way: A memoir. Honolulu: Centre for Pacific Island Studies, University of Hawai'i, p. 68.

6 Madraiwiwi, Ratu J. (2004). Advancing the role of women in decision making. Paper delivered to Women in Decision Making Conference organised by the Fiji National Council of Women, 15 November 2004, Nadi, Fiji Islands, p. 2. 
7 Constitution of the Republic of the Fiji Islands (27 July 1998). Section 38, (1) and (2)(a), p. 26.

8 Constitution of the Republic of the Fiji Islands. (27 July 1998), p. 42.

9 Constitution of the Republic of the Fiji Islands. (27 July 1998), p. 36.

10 Women in the Fiji House of Representatives, 2005: Representing the ruling Soqosoqo ni Duavata ni Lewenivanua Party: Adi Asenaca Coboiverata Caucau-Filipe (Tailevu South Lomaiviti, Open); Ro Teimumu Vuikaba Kepa (Rewa, Fijian Communal); Nanise K. Nagusuca (North East Urban, Fijian Communal); and Losena T. Salabula (Laucala, Open). New Labour Unity Party: Ofa Swann (Suva City, Open). Independent: Marieta Rigamoto (Rotuma, Rotuman Communal). Note: Adi and Ro are both chiefly titles in the Fiji Islands. Source: Fiji House of Representatives. (18 November 2005). www.parliament.gov.fj/mp/mp.aspx

11 Women in the Fiji Senate, 2005: Appointed by the Bose Levu Vakuranga (Great Council of Chiefs): Adi Koila Nailatikau. Appointed by the Prime Minister: Adi Litia Cakabau and Ro La Vuiyasawa. Appointed by the Leader of the Opposition: Dr 'Atu Emberson-Bain and Jokapeci Taiei Koroi. Fiji Senate. (18 November 2005). www.parliament.gov.fj/mp/senate.aspx

12 McAllister, I. and Studlar, D. T. (2002). Electoral Systems and Women's Representation: A Long-Term Perspective'. Representation, Vol. 39 No. 1: 9.

13 Drage, J. (2005). Women and the 2005 General Election. Women Talking Politics: Newsletter of the Aotearoa/New Zealand Women and Politics Newsletter, New Series Issue No. 4: 5-8.

14 Inter-Parliamentary Union. (2005). http://ipu.org/wnm-e/classif.htm

15 Mara. The Pacific way: A memoir, p. 68.

16 Rule, Wilma. (1987). Electoral Systems, Contextual Factors and Women's Opportunity for Election to Parliament in Twenty-Three Democracies. Western Political Quarterly, Vol. 40, No. 3, September: 494.

17 Rule, Wilma. (2000). Contextual barriers and benefits to women's parliamentary and cabinet representation in 68 democracies. Paper prepared for presentation at the 18th World Congress of the International Political Science Association, Quebec City, 1-5. Also Richard E. Matland and Donley T. Studlar (1996). The contagion of women candidates in single-member district and proportional representation electoral systems: Canada and Norway. In The Journal of Politics, Vol. 58, No. 3: 708.

18 Temple, P. (1998). Making your vote count: referendum '92: a guide to electoral reform. Dunedin: John McIndoe, p. 7.

19 Rabuka, S. (2002). Preferential voting and electoral reform. In Griffen, A. (Ed.), A citizens' review of the Fiji Islands general elections 2001, Suva, Fiji: Citizens Constitutional Forum, p. 73.

20 Reeve, A. and Ware, A. (1992). Electoral systems: a comparative and theoretical introduction. London: Routledge, p. 131. 


\section{CONTEMPORARY GENDER ISSUES}

21 Reeve and Ware, Electoral systems, p. 131.

22 Rule, Wilma. (1994). Women's underrepresentation and electoral systems. Political Science and Politics, December: 690.

23 Constitution of the Republic of the Fiji Islands, 27 July 1998, p. 36.

24 Fiji Elections Office. (12 November 2005). Elections 2001-Fiji Islands, www.elections.gov.fj/voter/how-to-vote.html.

25 United Kingdom Electoral Reform Society, (18 November 2005).

26 Reynolds, A. (1999). Women in the legislatures and executives of the world: Knocking at the highest glass ceiling. World Politics 51, July: 555.

27 Chandra, D. and Lewai, V. (2005). Women and men of Fiji Islands: Gender statistics and trends. Suva: Population Studies Programme, University of the South Pacific, p. 124.

28 Inter-Parliamentary Union. (21 November 2005). www.ipu.org/wmn-e/arc/ classif040202.htm.

29 Electoral Reform Society. (18 November 2005). www.electoral-reform.org.uk/ votingsystems/systems 2 .htm.

30 Narsey, Wadan. (2002). Preferential voting and electoral reform. In Griffen, A. (Ed.), A citizens' review of the Fiji Islands general elections 2001. Suva, Fiji: Citizens' Constitutional Forum, p. 78.

31 Matland and Studlar, The contagion of women candidates, p. 708.

32 Matland \& Studlar, The contagion of women candidates, p. 709.

33 Rule, Women's underrepresentation and electoral systems, p. 690.

34 Bogdanor, V. (1984). What is proportional representation? A guide to the issues. Oxford: Martin Robertson, p. 115.

35 Matland \& Studlar, The contagion of women candidates, p. 709.

36 Matland \& Studlar, The contagion of women candidates, p. 708.

37 Norderval, I. (1985). Party and legislative participation among Scandinavian women. In Bashevkin, S. (Ed.), Women and politics in Western Europe. London: Frank Cass, p. 82. Also Skard, T. and Haavio-Mannila, E. (1985). Women in parliament. In Haavio-Manilla et al, Unfinished democracy: Women in Nordic politics. Oxford: Pergamon Press, p.57.

38 Norderval, Party and legislative participation, p. 82-83.

39 Temple, Making your vote count, p. 17.

40 Norderval, Party and legislative participation, p. 82.

41 Inter-Parliamentary Union, (21 November 2005).

42 Welch, S. and Studlar, D. T. (1990). Multi-member districts and the representation of women: Evidence from Britain and the United States. Journal of Politics, Vol. 52, No. 2: 229 n. 76.

43 Engstrom, R. L. (1987). District magnitudes and the election of women to the Irish Dail. Electoral Studies, Vol. 6, No. 2: 129.

104 PACIFIC JOURNALISM REVIEW 12 (1) 2006 
44 Rule, Electoral systems, contextual factors and women's opportunity, p. 494. 45 Rule, Electoral systems, contextual factors and women's opportunity, p. 491; Darcy, Welch and Clark, Women, elections, representation, p. 229 no. 76.

46 Darcy, R. (1992). Electoral barriers to women. In Rule, W. and J. F. Zimmerman, (Eds.), United States electoral systems: Their impact on women and minorities. New York, Praeger: 228.

47 Darcy, Welch and Clark, Women, elections, representation, p. 167.

48 Welch and Studlar, Multi-member districts and the representation of women p. 395. Also Rule, Women's under-representation.

49 United Nations Office at Vienna. (1992). Women in politics and decisionmaking in the late twentieth century: A United Nations Study. Netherlands: Martinus Nijhoff Publishers, p. 41.

50 Darcy, Welch and Clark, Women, elections, representation, p. 160. The authors note that 'within certain constraints, each state is free to adopt legislative election methods best suited to its own political realities'. This freedom allows for many local variations.

51 Darcy, Welch and Clark. Women, elections, representation, p. 158.

52 Darcy, Welch and Clark. Women, elections, representation, p. 158.

53 Darcy, Welch and Clark. Women, elections, representation, p. 158-159. In May 1995, I spent one month carrying out field work for my PhD thesis in Guam. During that time, I spoke to all the elected women politicians in the Guam legislature as well as former politicians, political party officials, and academics, a total of 17 audiotaped interviews.

54 Nicholl, R. (2001). The woman factor: Candidate selection in the 1990sNew Zealand, Guam and South Africa, unpublished PhD thesis. Wellington: Victoria University, New Zealand.

55 Darcy, Welch and Clark. Women, elections, representation, pp. 158, 167.

56 Welch \& Studlar, Multi-member districts and the representation of women, p. 405.

57 Matland and Studlar, The contagion of women candidates, p. 710.

\section{References}

Bogdanor, V. (1984). What is proportional representation? A guide to the issues. Oxford: Martin Robertson.

Chandra, D. and Lewai, V. (2005). Women and men of Fiji Islands: Gender statistics and trends, Suva, Population Studies Programme, University of the South Pacific.

Commission on Gender Equality. (1999). Speech by President Nelson Mandela, opening South Africa's first democratically elected Parliament on 24 May 1994, Braamfontein, Commission on Gender Equality.

Constitution of the Republic of the Fiji Islands. (27 July 1998).

Darcy, R., S.Welch and J.Clark. (1987). Women, elections, representation (2nd ed. 


\section{CONTEMPORARY GENDER ISSUES}

rev.), Lincoln: University of Nebraska Press.

Darcy, R. (1992). Electoral barriers to women. In Rule, W. and J. F. Zimmerman (Eds.), United States electoral systems: Their impact on women and minorities. New York: Praeger, pp. 222-40.

Drage, J. (2005). Women and the 2005 general election. Women Talking Politics: Newsletter of the Aotearoa/New Zealand Women and Politics Newsletter, New Series Issue No. 4: 5-8.

Engstrom, R. L. (1987). District magnitudes and the election of women to the Irish Dail. Electoral Studies, Vol. 6, No. 2: 125-131.

Lijphart, A. (1984). Democracies: Patterns of majoritarian and consensus government in 21 countries. New Haven and London: Yale University Press.

McAllister, I. and D. T. Studlar. (2002). Electoral systems and women's representation: A long-term perspective. Representation, Vol. 39 No. 1: 3-14.

Madraiwiwi, Ratu J. (2004). Advancing the role of women in decision making. Paper delivered to Women in Decision Making Conference organised by the Fiji National Council of Women, 15 November, Nadi, Fiji Islands.

Mara, Ratu Sir Kamisese. (1997). The Pacific way: A memoir. Honolulu: Centre for Pacific Island Studies, University of Hawai'i.

Matland, R. E. and D. T. Studlar. (1996). The contagion of women candidates in single-member district and proportional representation electoral systems. Canada and Norway. The Journal of Politics, Vol. 58, No. 3: 707-733.

Narsey, W. (2002). Preferential voting and electoral reform. In Griffen, A. (Ed.), A citizens' review of the Fiji Islands general elections 2001. Suva, Fiji: Citizens Constitutional Forum.

Norderval, I. (1985). Party and legislative participation among Scandinavian women. In Bashevkin, S. (Ed.), Women and politics in Western Europe (pp. 71-89). London: Frank Cass.

Nicholl, R. (2001). The woman factor: Candidate selection in the 1990s-New Zealand, Guam and South Africa. Unpublished PhD thesis. Wellington: Victoria University,.

Rasigatale, M. (2003). Ro Teimumu-A Fijian princess. Suva, Fiji: Mak Heritage.

Reeve, A. and A. Ware. (1992). Electoral systems: a comparative and theoretical introduction. London: Routledge.

Report of the Royal Commission on the Electoral System. (1986). Towards a better democracy. Wellington, New Zealand.

Reynolds, A. (1999). Women in the legislatures and executives of the World: Knocking at the highest glass ceiling. World Politics 51: 547-72.

Rule, W. (1987). Electoral systems, contextual factors and women's opportunity for election to parliament in twenty-three Democracies. Western Political Quarterly, Vol. 40, No. 3, pp. 489-508.

Rule, W. (1994). Women's underrepresentation and electoral systems. Political Science and Politics, pp. 689-692.

Rule, W. (2000). Contextual barriers and benefits to women's parliamentary and cabinet representation in 68 democracies. Paper prepared for presentation at the 18 th

106 PACIFIC JOURNALISM REVIEW 12 (1) 2006 
World Congress of the International Political Science Association, Quebec City, 1-5 August 2000.

Skard, T. and E. Haavio-Mannila. (1985). Women in parliament. In Haavio-Mannila, E. et al. Unfinished democracy: Women in Nordic politics. Oxford: Pergamon Press, pp. 51-80.

Temple, P. (1992). Making your vote count: referendum '92: a guide to electoral reform. Dunedin: John McIndoe.

United Nations Office at Vienna. (1992). Women in politics and decision-making in the late twentieth century. A United Nations Study, Netherlands, Martinus Nijhoff Publishers.

Welch, S. and D. T. Studlar. (1990). Multi-member districts and the representation of women: Evidence from Britain and the United States. Journal of Politics, Vol. 52, No. 2, pp. 391-412.

\section{Online resources}

Fiji Elections Office, Elections 2001 - Fiji Islands, www.elections.gov.fj/voter/howto-vote.html (12 November 2005).

Fiji Department of Statistics. (21 November 2005). www.statsfiji.gov.fj/Key\%20Stats/ Population/2.4estimated\%20population.pdf.

Fiji House of Representatives. (18 November 2005). www.parliament.gov.fj/mp/mp.aspx.

Fiji, Senate. (18 November 2005). www.parliament.gov.fj/mp/senate.aspx.

Guam Election Commission. (15 March 2006). www.guamelection.org.

Inter-Parliamentary Union, Geneva. (21 November 2005). http://ipu.org/wnm-e/classif.htm.

Kuam Com, Pacific Telestations, Guam. (21 November 2005). www.kuam.com/decision 2002/generalelection/results.asp.

United Kingdom Electoral Reform Society. (18 November 2005). www.electoral-reform.org.uk/votingsystems/systems2.htm .

United Nations Children's Fund. (21 November 2005). www.unicef.org/infobycountry/fiji_statistics.html.

Dr Rae Nicholl is a lecturer in the World Politics Programme in the Department of History and Politics, University of the South Pacific, Suva, Fiji Islands.

nicholl_r@usp.ac.fj 